INEEL/EXT-99-01318

December 1999

\title{
Ventilation Systems Operating Experience Review for Fusion Applications
}

L. C. Cadwallader 


\title{
Ventilation Systems Operating Experience Review for Fusion Applications
}

\author{
Lee C. Cadwallader
}

Published December 1999

Idaho National Engineering and Environmental Laboratory

Idaho Falls, Idaho 83415-3860

Prepared for the

U.S. Department of Energy

Office of Fusion Energy Sciences

Under DOE Idaho Operations Office

Contract DE-AC07-99ID13727 


\begin{abstract}
This report is a collection and review of system operation and failure experiences for air ventilation systems in nuclear facilities. These experiences are applicable for magnetic and inertial fusion facilities since air ventilation systems are support systems that can be considered generic to nuclear facilities. The report contains descriptions of ventilation system components, operating experiences with these systems, component failure rates, and component repair times. Since ventilation systems have a role in mitigating accident releases in nuclear facilities, these data are useful in safety analysis and risk assessment of public safety. An effort has also been given to identifying any safety issues with personnel operating or maintaining ventilation systems. Finally, the recommended failure data were compared to an independent data set to determine the accuracy of individual values. This comparison is useful for the International Energy Agency task on fusion component failure rate data collection.
\end{abstract}




\section{SUMMARY}

This report is a collection of design and reliability information on ventilation systems applicable to magnetic and laser fusion experiments. Ventilation is an important plant system since it can control concentrations of radioactive particulate and gases, and also concentrations of toxicological materials. General ventilation system components are discussed, and typical equipment operating parameters are given. Design issues, such as air flow rates and ventilation zone pressures, are given from Department of Energy guidance and direction. Operating experiences with ventilation systems in nuclear facilities have been outlined to show the types of events that could occur. Sometimes, ventilation systems do not respond as desired in off-normal events. These experiences are applicable to magnetic and inertial fusion facilities since air ventilation systems are support systems that can be considered generic to nuclear facilities. Personnel safety issues for operators and maintainers have been addressed as well. Ventilation system component failure rates and representative average repair times have been selected from the literature. The chosen failure rate values have been compared to independent data from non-nuclear applications to determine how general the data values are between industries. Generally, military equipment data are the most rigorously collected and analyzed data after nuclear power plant data, and these values were used for comparison. Most of the comparison values were fair, and some values were poor. Nonetheless, the data presented are the most applicable for nuclear facility ventilation systems and can be used for safety or risk analyses of general ventilation systems at fusion facilities. 


\section{ACRONYMS}

AGS

AHU

ASHRAE

DOE

DOP

HEPA

HVAC

INEEL

ITER

NSSR-2 Non-site Specific Safety Report, revision 2

$\mathrm{Pa}$

PM

psig

RAM

rpm

TSTA

Vac

VFD

$/ \mathrm{d}$

$/ \mathrm{h}$

/h-m

American Glovebox Society

air handling unit Engineers

Department of Energy

high efficiency particulate air filter

Heating, Ventilating, and Air Conditioning

Pascal of pressure

preventive maintenance

pounds per square inch, gauge

reliability-availability-maintainability

revolutions per minute

Volts, alternating current

variable frequency drive

per demand to operate

per hour of operation

per hour of operation and meter of length
American Society of Heating, Refrigerating, and Air Conditioning

dioctyl phthalate, a chemical for testing filtration efficiency

Idaho National Engineering and Environmental Laboratory

International Thermonuclear Experimental Reactor

Tritium Systems Test Assembly at Los Alamos National Laboratory 


\section{TABLE OF CONTENTS}

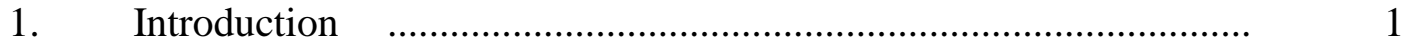

2. Ventilation System Operating Experiences......................................... 3

$2.1 \quad$ Ventilation system design ................................................... 3

2.2 Basic system components................................................... 7

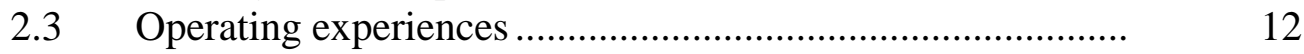

3. Ventilation System Personnel Safety Issues......................................... 21

4. Ventilation System Component Failure and Repair Rates ................. $\quad 30$

4.1 Component failure rates ...................................................... 30

4.2 Component repair times ...................................................... 33

5. Conclusions .......................................................................

Table 1. Recommended nuclear confinement system differential pressures $\quad 6$

Table 2. Suggested air change rates for nuclear confinement systems ........ 6

Table 3. Potential ventilation safety issues for operations personnel............ 23

Table 4. Potential ventilation safety issues for maintenance personnel ...... 25

Table 5. Ventilation system component failure rates ................................... 31

Table 6. Ventilation system failure rate comparisons $\quad$............................... $\quad 32$

Table 7. Repair time estimates for ventilation system components ............. 35

Figure 1. Typical ventilation zone design.................................................... 


\section{VENTILATION SYSTEMS OPERATING EXPERIENCE}

\section{REVIEW FOR FUSION APPLICATIONS}

\section{INTRODUCTION}

During the course of the International Thermonuclear Experimental Reactor (ITER) engineering design, analysts noted that many of the postulated accident events discussed in the Non-site Specific Safety Report (NSSR-2) ended in a stack release of radioactive or chemical effluents to the environment. Releasing radionuclides from the stack provides two important safety-conservative features. The release is elevated, which leads to better dispersion in the atmosphere than a ground level release. The other feature is that the radionuclides are also mixed with the high flow rate stack air, which leads to diluted concentrations of the radionuclides. Both of these features are important to reduce the radiological dose to the public. Maintaining a stack release rather than a ground level release was important for meeting safety objectives of the ITER design (FDR, 1998).

Typically, a heating, ventilating, and air conditioning (HVAC) system provides for human comfort by supplying appropriate air quality, maintaining comfortable temperature and humidity conditions, and providing filtration of building air for cleanliness and freshness. Air circulation may also be used for heat transfer from some types of powered equipment, such as electrical motor control centers. For nuclear fusion facilities, including tritium handling facilities, these ventilation functions must be directly coupled to the confinement function for radionuclides (tritium, activated dusts, and any other activated gaseous or aerosol materials). While detritiation systems operate to remove tritium from the air in a room so that the air can be released, the ventilation system must isolate to work in cooperation with the detritiation system. This cooperation is needed so that the room air is not vented to the facility stack before it has been detritiated to an appropriate level. The ventilation system is also responsible for filtering radioactive aerosols from the air before stacking the air to the environment. Filter media or scrubbers might accomplish filtration. These cooperative functions make the ventilation system very important for mitigating possible accidents at a fusion facility.

Ventilation systems are not a trivial support system. Ventilation is an important confinement barrier for radiological, biological, or toxicological hazards. Considering the Sellafield reprocessing plant, the three-building complex has 58 fans, 1,000 dampers, and 10 miles of ductwork. The ventilation system capital cost was $£ 11 \mathrm{M}$, or about $3.5 \%$ of total facility construction cost. The electricity to run the fans costs over $£ 20 \mathrm{M}$ per year. This cost does not include the replacement filter costs or any other maintenance cost (Doig, 1998).

This report addresses ventilating system component technology, operating experiences, personnel safety issues related to ventilation, the component failure rates and repair rates of ventilating system components. Ventilation is the focus here rather than the entire HVAC system. 


\section{Section 1 References}

Doig, 1998. R. Doig et al., "Ventilation Design for Containment and the Effects on Energy Consumption at Sellafield," The Nuclear Engineer, $\underline{38}$, 1998, pages 131136.

FDR, 1998. Technical Basis for the ITER Final Design Report, Cost Review and Safety Analysis (FDR), ITER EDA Documentation Series No. 16, International Atomic Energy Agency, Vienna, December 1998, chapter IV, section 3. 


\section{VENTILATION SYSTEM OPERATING EXPERIENCES}

This section summarizes some operating experiences from nuclear ventilating systems. These experiences provide insights to possible initiating events involving the ventilating system. While these systems are not thought to retain radioactive or hazardous materials, there can be material buildup in the filtration units, and aerosol particles have been known to plate out on the duct interior, so these materials slowly accumulate over time and could be released in a system off-normal event.

This section begins with a brief description of the design philosophy used for nuclear ventilation systems. Then the technology used with basic components found in ventilating systems is discussed.

\subsection{Ventilation system design}

Ventilation is always arranged to sweep air from uncontaminated areas to mild contamination or potentially contaminated areas, then to more heavily contaminated areas if the designer anticipates such contamination. Then the air is filtered to remove particulate and then is stacked to the atmosphere. Figure 1 shows the design air flow direction for nuclear confinement as defined by the American Society of Heating, Refrigerating, and Air-conditioning Engineers (ASHRAE) (ASHRAE, 1993). This type of air flow is typical for radioactive contamination areas, so that contamination is not spread by flowing air to lesser contaminated areas. The reverse of this air flow pattern is used in clean rooms, where the primary concern is to filter and slightly pressurize air in the primary room; letting air leak outward to other rooms. In that way, the clean room does not have any admission of dust, aerosols, or other contaminants into the clean room processes. This report will focus on ventilation systems used for radioactive zoning, as depicted in Figure 1.

Department of Energy (DOE) ventilation design guidance (ASHRAE, 1993; DOE, 1999) suggests that for primary confinement, such as gloveboxes, the volumetric air change rate should be up to 30 air changes per hour. This is a very high flow rate and may be warranted for some applications. Some typical glovebox air change rates used in practice for gloveboxes that handle particulate are 5 to 7 air volume changes per hour (Cadwallader, 1998). The primary confinement glovebox design at the Tritium Systems Test Assembly (TSTA) does not continually purge the gloveboxes. A set of solenoid valves control nitrogen gas inflow from the gas storage system and outflow to the gas cleanup system. When glovebox pressure changes, tritium over $1 \mathrm{mCi} / \mathrm{m}^{3}$ is sensed, or oxygen content greater than $2 \%$ is sensed, the controller opens the nitrogen supply and exhaust valves (Cadwallader, 1992). For the 13 full-time glove- boxes at TSTA, varying between 1 to $3.6 \mathrm{~m}^{3}$ volume for a total of $29 \mathrm{~m}^{3}$, the nitrogen gas flow rate is between 10 to $15 \mathrm{~m}^{3} /$ hour. If all gloveboxes were to draw nitrogen flow, the flow rate would be about $30 \mathrm{~m}^{3} /$ hour. Therefore, the average gas purging is between 0.33 to 0.5 nitrogen changes per hour, with a peak of about 1 change per hour. If only one glovebox needs to be swept, it can change between 4 to 10 nitrogen volumes per hour. 


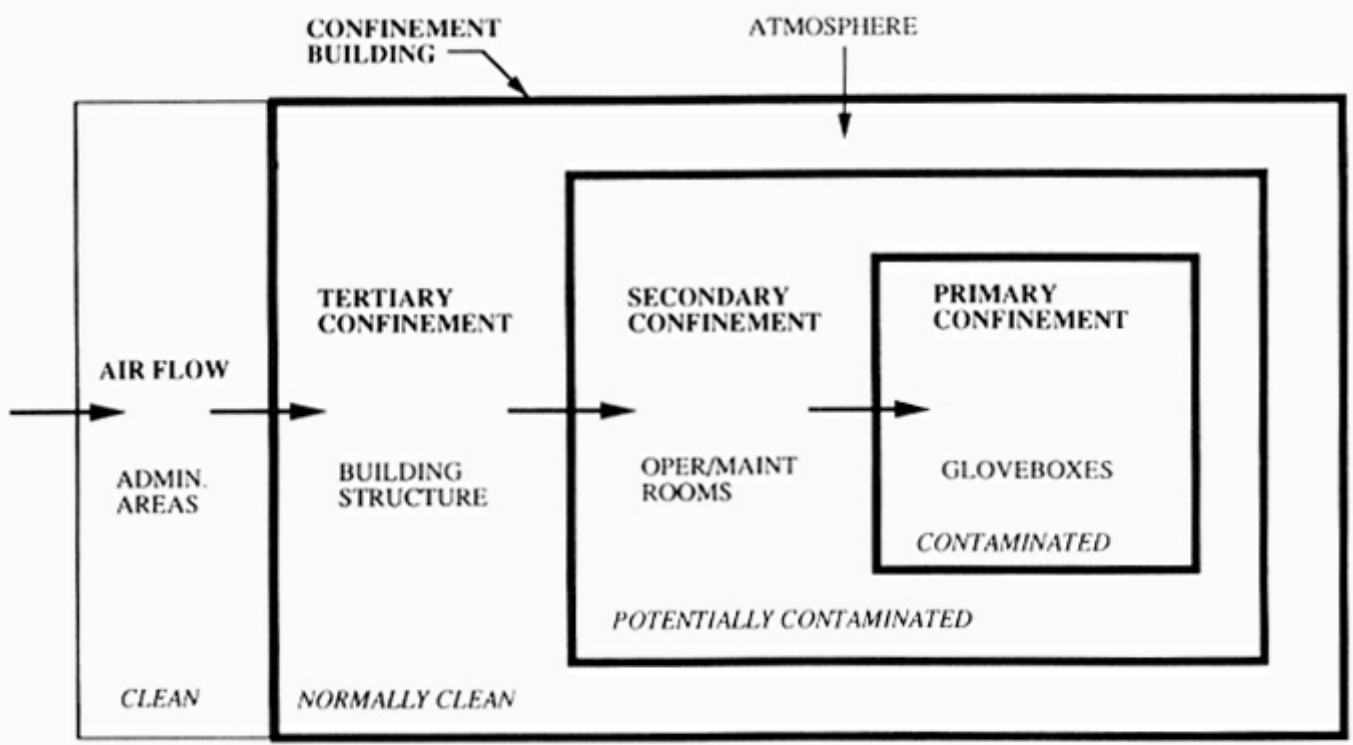

Figure 1. Typical ventilation zone design. 
The recommended confinement system differential pressures are given in Table 1 (ASHRAE, 1993). The TSTA gloveboxes operate at $500 \mathrm{~Pa}$ below normal atmospheric pressure for Los Alamos. The atmospheric pressure at Los Alamos is about $78.6 \mathrm{kPa}$ at that altitude. Initial operation of the gloveboxes was at static (atmospheric) pressure to $500 \mathrm{~Pa}$ above atmospheric pressure because of concerns for air inleakage that could have led to tritium conversion to the more hazardous oxide form, or to combustion. After several years of operation, a change was made to operate at $500 \mathrm{~Pa}$ below atmospheric pressure. This change was made to reduce the likelihood of tritium leakage into the room that housed the gloveboxes. The $+500 \mathrm{~Pa}$ glovebox experiences had shown that the concern about air inleakage was not as important as the chance of small amounts of tritium leaking into the room. While the TSTA negative pressure is lower than the pressure recommended in Table 1 and means that there might be extra expense to treat the nitrogen atmosphere, it is safety conservative.

Another important ventilation requirement is the velocity to move air through a breach opening. Considering a glovebox as the primary confinement, there has long been a guideline of drawing at least $100 \mathrm{feet} / \mathrm{minute}$ velocity of air or gas through a breached gloveport (Walton, 1958; Burchsted, 1976; ASHRAE, 1993). The American Glovebox Society (AGS) suggests $125 \pm 25$ feet/minute air flow into a breached gloveport (AGS, 1998). Similar velocities of 60 to $100 \mathrm{feet} / \mathrm{minute}$ are also suggested for laboratory hood openings. That air velocity provides a laminar flow of air over the hood floor and wall surfaces. Higher speeds, over $125 \mathrm{feet} /$ minute, will lead to air turbulence and to the waste of stacking comfortable room air and increased energy use for fans. Air turbulence can cause vapors within the hood to be spilled from the hood to the room (NRC, 1981).

Design guidance for ventilation of secondary confinement zones is 4 to 8 air changes per hour, to be compared against cooling requirements and makeup (outside) air requirements to verify adequacy. The makeup air requirements for fume hoods, open-faced hoods, local exhaust ventilation, sweep air over benchtop radioactive experiments, etc., can dictate the ventilation rates for secondary confinement zones (ASHRAE, 1993). This guidance is not always met; some facilities will operate with perhaps 2 or 3 air changes/hour in the secondary ventilation zone. Table 2 gives suggested air change rates.

Tertiary ventilation zones are radiologically clean areas that often contain offices or other administrative areas, non-radiological (referred to as "clean") workshops, storage rooms, receiving areas, etc. The ventilation requirements will depend on the air cooling and quality needs when selecting the air change rates. As a comparison, a typical office might change air at 0.5 to 2 changes per hour. Typical residential homes might have 0.33 to 0.5 air changes per hour by natural draft and leakage. A very tightly built, well insulated house might be in the 0.1 air change per hour range, while a drafty, loosely constructed home (loose windows, etc.) can have well over 1 air change per hour.

Another ventilation system of interest to mention here is the system designed for the Beryllium Technology Facility at Los Alamos. This facility is being fabricated from an existing building at Los Alamos. New ventilation systems are being installed for this 
Table 1. Recommended nuclear confinement system differential pressures

\begin{tabular}{|c|c|c|c|}
\hline \multirow{2}{*}{ Type of facility } & \multicolumn{3}{|c|}{ Differential Pressures (Pa) } \\
\cline { 2 - 4 } & $\begin{array}{c}\text { Primary zone to } \\
\text { secondary }\end{array}$ & $\begin{array}{c}\text { Secondary zone to } \\
\text { tertiary }\end{array}$ & $\begin{array}{c}\text { Tertiary zone to } \\
\text { atmospheric } \\
\text { pressure }\end{array}$ \\
\hline New facility & -174 to -248.6 & -24.8 to -37 & -24.8 to -37 \\
\hline Existing facility & -75 to -248.6 & -7.5 to -37 & -2.5 to 37 \\
\hline
\end{tabular}

Confinement canyons or cells operate with a - 248.6 Pa pressure as a minimum

Gloveboxes with air, typically operate at -174 to $-248.6 \mathrm{~Pa}$

Gloveboxes with air typically have pressure alarms set at $-124 \mathrm{~Pa}$

Gloveboxes with inert gas, typically operate at -174 to $--373 \mathrm{~Pa}$

Notes:

Sometimes a ventilation zone can be split into two areas, where one area has a greater hazard than another area.

Glovebox pressure relief valves are typically set at $-99 \mathrm{~Pa}$ when needed in a design.

Table 2. Suggested air change rates for nuclear confinement systems

\begin{tabular}{|c|c|c|c|}
\hline \multirow{2}{*}{ Type of facility } & \multicolumn{3}{|c|}{ Suggested air exchange rate (air changes per hour) } \\
\cline { 2 - 4 } & $\begin{array}{c}\text { Primary } \\
\text { confinement }\end{array}$ & $\begin{array}{c}\text { Secondary } \\
\text { confinement }\end{array}$ & $\begin{array}{c}\text { Tertiary } \\
\text { confinement }\end{array}$ \\
\hline \multirow{2}{*}{ New facility } & Up to 30 & 4 to 8 & 0.5 to 2 (typical) \\
\hline & $\begin{array}{c}\text { Often } \\
\text { less than } 10\end{array}$ & $\begin{array}{c}\text { Often at } \\
2 \text { to } 3\end{array}$ & $\begin{array}{l}\text { Often at } \\
0.33 \text { to } 2\end{array}$ \\
\hline Existing facility &
\end{tabular}

Notes:

Tertiary confinement air exchange rates may be dominated by ASHRAE requirements for clean air per person in the occupancy rather than radiological control issues. 
beryllium machining and handling operation. The general room ventilation will be once through with 15 air changes per hour, and there will be local exhaust ventilation at point of operation for polishing, grinding, lathing, milling, and cutting operations as well as joining, coating, and other operations. The ventilation is not energy efficient, but it is a robust system for worker protection. The air enters the ventilation system through prefilters (30\% efficient filters) then through 95\% efficient filters for 5 micron size particles. The air then enters two half-capacity air handling units. These variable frequency drive (VFD) fans route air to the facility ventilation systems. Exit air from the local exhaust ventilation systems is drawn by a high pressure blower ( 250 horsepower) and sent through a filter house $(99.999 \%$ efficient for 0.5 micron particles) and then to a high efficiency particulate air filter bank (99.97\% efficient for 0.3 micron size particles). The two full-capacity VFD exhaust fans take the general room air flow and draw the air through the same high efficiency filter bank. Then the air is sent the $20 \mathrm{~m}$ tall exhaust stack (also called an ejector). The air flow patterns in the rooms are ceiling diffusers with downward air flow, with exhaust air intakes near the floor level. This flow pattern reduces the particulate in the worker's breathing zone. The air pressure is monitored throughout the ventilation system, as well as flow, temperature, and humidity. When pressure changes across the filters grow too large, the filters are changed. The facility must go to reduced operation status during filter changeouts and other ventilation system maintenance. The ventilation ducts will have fire detectors, and a mist humidifier is used to maintain building humidity in the $25-30 \%$ range (Abeln, 1998).

\subsection{Basic system components}

A typical set of components are found in ventilation systems; these components are listed in (DOE, 1994) and are given below:

Air sampling devices

Filters (carbon bed absorbers, absorption, HEPA, sand, glass fiber) and pre-filters

Scrubbers

Demisters

Vessel vent systems

Condensers

Distribution baffles

Fire-suppression systems

Fire and smoke dampers

Exhaust stacks

Fans

Coils

Heat removal systems, such as chilled water systems

Pressure and flow monitors

Radiation-monitoring devices

Criticality safe drain systems

Tornado dampers 
Of these components, the fan is the prime mover and can be considered the heart of a ventilation system. Ninety-nine percent of all air-moving applications are handled by three types of fans: centrifugal, propeller, and axial units (Reason, 1983). The fan wheel geometry determines the shape of a fan's pressure-flow characteristic curve, but the fan must be correctly sized for its application to operate efficiently. Nuclear air cleaning fans are required to provide trouble-free service for long periods to time with a minimum of maintenance. Centrifugal fans are capable of providing that service when chosen carefully. Experience with in-line centrifugal and vane-axial fans has shown that these units are also attractive since they have given good service. Their straight through design allows them to tolerate shock waves more easily than centrifugal fans, and these units also withstand high humidity and temperature without failure or loss of efficiency (Burchsted, 1976). Fans typically operate between 600 and $3600 \mathrm{rpm}$, with size depending on the quantity of air to be moved. A typical centrifugal fan for industrial operations might operate at $600 \mathrm{rpm}, 500 \mathrm{~Pa}$ ( 2 inches of water), $115 \mathrm{~m}^{3} /$ minute $(4100$ feet $^{3} /$ minute) at 3.7 kilowatts input power (Grimm, 1998). The term blower is also used for ventilating fans, generally large fans. Ventilation systems in nuclear power plants typically run continuously to provide the subatmospheric room or zone pressures described in this section. Containment fan cooler systems also run continuously to keep the containment building air temperature down below high levels that could affect equipment or people. Mechanical and electrical equipment can suffer degradations at high temperatures from loss of adequate lubrication or weakened electrical insulation. Personnel should not work for any long period to time in rooms whose air temperature is above $135^{\circ} \mathrm{F}$ (Bongarra, 1985).

Typically, fans for ventilation do not generate high pressures. Instead, fans induce high velocity in the air to move large quantities of air through ducts. Fans may stand alone, but are typically built into air handling units (AHUs), that include dampers, air heating/cooling coils, ductwork connections, and a metal casing (Levenhagen, 1993; Mull, 1998). The air heating coils may be electrically heated or steam heated. A humidifier may also be a part of the AHU, either a steam jet humidifier, a pan-type humidifier where water is evaporated into the air stream by electric heat or steam heating, or a water atomizer. Often the fan in an AHU is a centrifugal unit. AHUs are found in fission power plants (Lish, 1972) as well as fusion experiments, such as the Tokamak Fusion Test Reactor and other experiments. The technology for moving air is used equally well in both applications.

Air is typically routed using ducts or duct work. For offices and commercial buildings, the ducts are generally rectangular cross section and made of sheet metal sections with lock seams. This type of duct work might be used in some nuclear facilities for nonradiological areas, but the typical nuclear duct work is piping that meets American Society of Mechanical Engineers code requirements for integrity during seismic events and withstanding external pressures of accident events, up to 60 psig (Lish, 1972). This welded piping is much less prone to leakage than sheet metal ducts. The air piping can be stainless steel or carbon steel (ASME, 1989). 
Dampers are used to control the flow of air in the fan exhaust and in ducts. Dampers can either stop/start the flow of air or they can be used to mix air streams. Usually, nuclear applications use butterfly valves for stopping flow and dampers to route or mix air flows. Parallel blade dampers are the most widely used type of damper (Levenhagen, 1993). A parallel blade damper is a horizontal set of aluminum, steel, or other metal plates (blades) in the air stream. These blades pivot on their long axis to overlap each other when they close so that air flow paths are closed off in the duct. As the blades pivot to open, flow areas are uncovered to allow air flow. Partial closure deflects the flowing air as needed for mixing air streams. The damper blades are driven by either pneumatic or electric motors that are attached to linkage arms. The linkage arms generally only move when force is applied, but can also be designed to fail in a specified position. For pneumatic motors, air pressure in the 3 to 15 psig range works against a diaphragm and a spring. A linkage arm is attached to the diaphragm, so that when the diaphragm moves, the linkage transmits force to the blades and they in turn move. Electric damper motors are typically induction motors operating at 24 Vac (Levenhagen, 1993). The motor shaft is attached by a gear set to the blade arm linkage.

Fire dampers and smoke dampers are special classes of dampers and are only used for safety in fire situations. Fire dampers are used to stop the spread of fire and confine a fire to one area of the duct work. They are built of metals that can withstand fire heat without losing strength, and are not axially pivoted blades like air flow control dampers. A fire damper may be a curtain type, a single blade, multiple blades, or interlocking blades (Cote, 1991). A fusible link must melt at a specified temperature, usually $74^{\circ} \mathrm{C}\left(165^{\circ} \mathrm{F}\right)$, to allow a coiled spring to close a fire damper (Mull, 1998). The damper will remain closed until manually reset. A smoke damper can be pivoted blades like air control dampers, and can be motor-controlled or spring loaded to close on a smoke sensor signal. Smoke dampers are typically rated for leaktightness, such as $1 \%$ of the duct design air flow is allowed to leak past the closed blades (Levenhagen, 1993). This measure is a means to demonstrate the ability of the unit to control smoke during fire situations. Controlling smoke means less smoke inhalation exposure to the people who are evacuating the building, better visibility, and generally less induction of panic among evacuees. In a loss prevention sense, controlling smoke means less chance of spreading the fire, and reduced building damage from smoke and heat. The smoke dampers are called for on systems whose capacity exceeds 7,080 liters/second air flow (Grimm, 1998). These dampers must also withstand high heat from the hot combustion products found in smoke, but the design codes are usually not as stringent for smoke dampers as for fire dampers (Levenhagen, 1993).

Tornado dampers are another type of safety damper. These are used for isolating the ventilation system when tornado winds cause pressure changes around a building, and when tornado winds drive outside air through a ventilation system at higher flows than normal operations. Typically, ordinary wind will create some pressure changes as it flows around a building, but the pressures are small, perhaps as much as a few 10's of Pascals. Strong winds could cause 100's of Pascals pressure change (Simiu, 1986). Even this small pressure can cause air to flow from a building toward the low pressure area, but 
tornado force winds can cause thousands of Pascals pressure difference that can reverse air flow in ventilation systems (Howard, 1983).

The air flow isolation device used in nuclear air ventilation ducts is the air valve. This valve is similar to a water flow valve. These steel butterfly-type valves might be large, such as $1.2 \mathrm{~m}$ (4 feet) flow diameter. The valves must withstand high pressure (up to 60 psig) and perhaps steam temperatures of several hundred degrees C. Air operators for these valves typically require pressure in the 100 psig range (Lish, 1972). Valve seats can be elastomer soft seats for a pressure-tight seal. Sometimes the term "bubble-tight" seal is used to mean positive results from a field leak test. The test method applies a waterand-soap solution to the sealing surface of a valve closed against air pressure on the far side; if the test does not produce any discernible bubbles from air leaking past the valve seat then the valve is leak-tight or "bubble-tight".

Ventilation system filters are used to remove particulate from the air stream. Particles can cause safety concerns for personnel and the environment. Particles also can lead to problems with the fans. Particles striking the fan blades cause wear, and over time the fan can become unbalanced from blade wear. Particles that are combustible in air can be ignited by striking the fan impeller, or by the motion of the impeller in the fan casing (ACGIH, 1995). Other types of filters, such as charcoal filters, can remove vapors from the air stream. The basic type of filter used for nuclear applications is the high efficiency particulate air (HEPA) filter. This filter, by law, must remove $99.97 \%$ of mono-disperse particles 0.3 micron diameter (see 29CFR1910.1001) and larger. However, another part of the Code of Federal Regulations directs that the HEPA filter reduces emissions by $99 \%$ (an adjustment factor of 0.01) (40CFR61, appendix D). Since these filters must capture so many radioactive or toxic particles, the filters are known to accumulate an inventory of hazardous materials (see DOE, 1997). Hazardous releases from the filters themselves are studied, such as filter fires and filter rupture from overpressure or other causes. There is a large potential for filter oxidation due to the high air flow that continuously feeds oxygen (Grimm, 1998). Filter media are chosen for low flammability, but can still burn under adverse conditions. An example of filter release studies is WHC (1996). Some filter tests with hydrocarbon fires have showed that the smoke cools before reaching the filters and particulate loading is not too severe (Hasegawa, 1992), but this result could be dependent on the amount of combustion mass.

A HEPA filter is constructed of pleated panels of a glass fiber 'paper' arranged in a frame with metal separators between the pleats. Filters can be either rectangular or circular. The filter's glass fiber media gives high efficiency in particle removal from the air, by particle diffusion into the media, particle impaction onto the media, and particle interception. The media depth in the direction of air flow is usually over $30 \mathrm{~cm}$ to provide a large amount of filter material surface area for cleansing efficiency without creating too much pressure drop across the filter. Filter pressure drops, also called filter resistance, can be in the range of 125 to $500 \mathrm{~Pa}$ ( 0.5 to 2 inches of water pressure) (Mull, 1998). The filter resistance increases as the particulate loading increases. Filter replacement is recommended when the filter resistance has doubled, or reached the 
manufacturer's suggested limit (DOE, 1994). A HEPA filter weighs on the order of 18 $\mathrm{kg}$ for a $28.3 \mathrm{~m}^{3} /$ minute rated unit of $0.6 \mathrm{~m} \times 0.6 \mathrm{~m} \times 0.3 \mathrm{~m}$ deep. Dirty filters can weigh another $1.8 \mathrm{~kg}$ per $28.3 \mathrm{~m}^{3} /$ minute $(1000 \mathrm{cfm}$ ) of rated capacity (Burchsted, 1976).

Rudinger (1990) gives a good summary of HEPA filter construction, operation, and filter safety issues that face the nuclear industry. HEPA filters are a relatively fragile component compared to metal ducts and valves, but they are part of the confinement barrier. There are concerns about high humidity air flow to the HEPA, since lading the glass fiber material with water can reduce the strength of the filter media so that its pleats might easily tear. Another concern is about loading with smoke particulate from a fire. After clogging the filter and having the fire heat and smoke increase building atmosphere pressure, the filter could fail. Pressure impulses, such as explosions in the duct work or sustained tornado winds, a damper spurious closure, or even a high volume cryogen spill that cools and shrinks, then undergoes boiling expansion that swells the building air volume could potentially fail one or more filters. Generally, unusual events of this nature are needed to fail the filter, and inherent flaws that allow the filter to "leak past", that is, to allow unfiltered air flow past the filter, are very rare. No internal leakage failure rate attributable to the filter itself was found in the literature for HEPA filters. HEPA filter breakthrough means that the filter is saturated and will no longer retain any captured particulate from the air stream. Such a filter must be replaced to regain proper air filtration. Filter changeouts depend on the particulate concentration at the facility, but changeouts of every 6 months to a year are not uncommon. Some facilities that are relatively clean might operate two years or longer before HEPA changeout (Winegardner, 1993).

Charcoal filters can adsorb gas molecules. The charcoal is very porous, creating a very large surface area for gas molecules to diffuse and bond onto the walls of the pores. Carbon (charcoal) on the order of $0.5 \mathrm{~kg}$ can adsorb up to $0.25 \mathrm{~kg}$ of gases (Mull, 1998). The filters are most effective when the air and contaminants are kept in contact with the filter. Air velocities under $150 \mathrm{~m} /$ minute should be used, and pressure drops for these filters are on the order of 50 to $75 \mathrm{~Pa}(0.2$ to 0.3 inches of water). The maximum operating temperature is about $38^{\circ} \mathrm{C}\left(100^{\circ} \mathrm{F}\right)$. Higher temperatures can cause the carbon to desorb gases.

A sand filter consists of multiple beds of sand and gravel. Air is drawn through these beds. The air flows at a velocity of perhaps $1.5 \mathrm{~m} /$ minute through the layers of sand. Then the air is discharged.

Both the HEPA and carbon filters will use a pre-filter to capture the larger diameter particulate dust before it enters the main filter. A pre-filter is typically a thin pleated paper or fiber glass filter that can capture larger micron size particles. Burchsted (1976) gave guidance that a pre-filter should always be used to prevent a HEPA from loading up or "caking" with large diameter particles. Davis (1999) showed that prefilters can extend the useful life of HEPA filters. 
A demister is often used in the ventilation system as well. These units are sometimes called mist eliminators. A demister operates to remove moisture droplets, so that filters do not become loaded with the moisture. Penicot (1999) showed with experiments that liquid aerosol particles, smaller than water droplets, tend to clog a HEPA filter slower than solid aerosols, but there are additional concerns that the liquid will weaken the filter media or its attachment to the filter frame, allowing the filter to leak air without filtration. Demisters can come in several types. Wire mesh screens will capture larger droplets, and torturous path chevron "wave-plate" units will capture droplets in the 100 micron range. For capturing small droplets in the 10 micron range, demisters are fiberglass cloth on a wire mesh matrix. The resistance (pressure drop) across the filter is on the order of 250 $\mathrm{Pa}$ when dry, but this value increases as the demister collects more and more water (Burchsted, 1976).

\subsection{Operating experiences}

Some ventilation operating experiences from various nuclear applications are discussed in this section.

At an experimental fission power reactor at the Idaho National Engineering and Environmental Laboratory (INEEL), a review of two recent years' of log book entries revealed these types of faults and concerns with the facility ventilation systems:

- Fan motor grounded, fan not operating

- Fan spurious trips (unknown reason, fan restarted)

- Fan vibration trips, fan successfully restarted each time

- Fan speed controller trips, fan successfully restarted each time

- Bad bearings found in fan shaft, fan was taken out of service to install a new bearing

- Fan belt failure in a belt drive, belt replaced and retensioned

- Fan belts loose, tightened belts

- Smoke dampers not found at a location in the ventilation system, even though they were

specified as being in that location in the system design

A Department of Energy report (DOE, 1994) has also documented ventilation system operating experiences at DOE facilities. That work reviewed DOE occurrence reports that dealt with ventilation components or systems. The most important issues found in that report are discussed here. One facility found that the ventilation system was failing surveillance tests since the air filters were dirty and were not being changed periodically. The filters had been in place for up to 18 months without changeout. In other facilities, workers accidentally bumping switches and/or motor starters, causing fans to lose electrical power. Most of the cases were due to close quarters where the switches were located. Another facility was undergoing maintenance on fans. One fan shut down; the other fan was not sending enough air flow. Investigation revealed that a process damper had been pinned in place so that it would not respond to actuation. The damper had a history of difficulty with its pneumatic actuator, so it had been pinned in a fixed position. 
The damper was changed to a manual open/close damper. In a configuration management problem, an operating procedure did not reflect the system configuration. With preventive maintenance being performed on a computer control system, power to the computer was secured. An interlock then also shut down the facility ventilation system, and it remained off for nearly 2 hours. Another facility was supposed to annually test its air filters using a standard chemical material called dioctyl phthalate (DOP). The facility was testing the filters at every 15 months rather than 12 months.

Several equipment aging problems were also noted. In a test to simulate the loss of offsite power, a control system relay failed to change state, so the ventilation system did not restart on alternate power. Several relays were found to be aged; they were replaced. Some ventilation fans were powered by electricity from diesel generators, and the diesel engines had wear problems. Typically for fusion, the systems are considered to be powered from off-site electrical power, not from dedicated diesel generator units. Some other aging problems were fan rotor bearing failures (overheating, smoking, noises from running rough, etc.). Some air filters (13 of 45 at one facility) were found to be defective, physically separated from their frames so that air could pass through unfiltered. This discovery is comparable to the percentage quoted by Wilhelm (1987), who suggested that up to $15 \%$ of filters in service are leaking air past the filter media due to pleat tearing and media separation from the frame. The leaking air filters showed an efficiency of $97.90 \%$, while they should have had an efficiency of $99.95 \%$. Some safety work has taken into account reduced filter efficiency by giving degraded filters a reduced efficiency of $90 \%$ (Holland, 1991). In environmental impact studies, HEPA filter failure scenarios give the filters zero filtration (NPR, 1991).

Fans showed many problems in the occurrence reports, followed by modest numbers of filter problems, the circuit breakers, motors, controllers and instruments, dampers, electrical connections, relays, ducts, gaskets, and switches. Fortunately, quite often fans are sized to $100 \%$ capacity, so only one fan operating will provide adequate air flow for an area or facility. This redundancy is quite useful to allow on-line maintenance of failed units.

Moeller (1975) cataloged other nuclear industry experiences. These experiences showed that fires and explosions have occurred in ventilation systems, particularly in power plant off-gas systems that handle hydrogen gas. Filters have also become contaminated with moisture, lubricating oil, and process chemicals, such as acids. Isolation butterfly valves have been noted to not fully close due to debris accumulation in the valves. Other miscellaneous problems included fans not being turned on, nitrogen gas purge flow continued during a filter changeout, and a fan wired to rotate in the wrong direction. Moeller (1979) then cataloged other, later experiences with these systems. Sampling air and monitors in ventilation systems gave half of the reported failure events in the period 1975 to 1978. The air sampler failures did not detract from system operation, but did cause problems in meeting specifications for testing the air. An important event from 1976 was also mentioned there, ice buildup in the upper portion of an exhaust stack at a boiling water reactor. Exhaust air backed up into the off-gas building. The air was rich 
in hydrogen, and the hydrogen deflagrated. The off-gas building was demolished (Bertini, 1980). Further work by Moeller (1983) showed that fan cooling coils have had leaks, in some cases very large leaks $\left(380 \mathrm{~m}^{3}\right.$ or 100,000 gallons) before the leak was discovered and the water could be isolated. Various blower failures were given, as well as cases of dampers failing to change state, depleted charcoal adsorber and air filter plugging. Hydrogen monitors also gave problems, not reading correctly. Jacox (1989) carried on with the experience work, noting spurious alarms from radiation monitors, failures of toxic gas detectors, and water admission into activated carbon filters.

There are also some ventilation system general safety concerns and issues from the literature. Ventilation systems have been known to retain particulate in their ducts. The Pacific Northwest Laboratory and the Rocky Flats facility have discussed the holdup of plutonium dusts in the duct work (Haggard, 1996; Beckman, 1993). A facility in Kazakhstan was said to have had beryllium dust held up in the ventilation system, and during a process deviation from normal, the dust exploded (OHS, 1990; NW, 1990). Toxic and combustible dusts are not the only substances held up in ventilation systems. Grimm (1998) and Levenhagen (1993) also discuss that the bacteria Legionalla pneumophilia has grown in trays or pans for condensate water collection and humidification in ventilation systems, and while no outbreak of Legionnaire's disease is officially attributed to the bacteria, exposure to the bacteria is not safe.

Another important aspect of ventilation is that the system ducts can become a conduit to bypass confinement if the system isolation valves do not function to seal the ducts when needed. Unless the ducts are sealed, unwanted consequences can occur. Lees (1996) gave an example of ducts propagating an unwanted event. A phenolic resin plant in New Jersey was handling resin powder. The probable chain of events was that a bearing in a hammer mill shredder overheated, causing resin powder in the mill to overheat. The powder passed on to the dust collector. A dust explosion occurred in a dust collector, and the explosion shock waves traveled down the process ducts and broke through them, emerging at several locations in the facility. The released shock wave pressure energy raised clouds of resin dust in the plant. Those dust clouds exploded in several violent secondary explosions. Five people were killed in the explosions, over 20 more were injured. This event illustrated how the ducts can channel explosive energy to result in a much higher consequence event. Ventilation systems may have combustible dusts or vapors confined in the ducts and filters. Confining a combustible material could allow a subsonic deflagration event that yields modest overpressure energy to accelerate to a supersonic detonation event that yields very high overpressure energy. Deflagration to detonation transition is due to shock wave reflection and buildup, and pre-heating of the unreacted media in a confined area. When combustibles are going to be handled at a facility, the ventilation system can incorporate several protective features. Some of these features are dust (or other material) collectors to keep concentrations below combustible levels and detection sensors to monitor concentration of the combustible substance. An example of monitoring is a combustible gas monitor that alarms at $25 \%$ of the lower flammable limit of the gas in air. The ventilation system can be fitted with explosion vents to direct explosion energy into inconsequential and unmanned areas, explosion 
suppression systems that quickly act to break up the combustion wave front, and blow out panels so that overpressure is dissipated without damage to people or equipment.

Ventilation systems also can be compromised by intake of air that is not fresh and clean. Industrial complaints have occurred when air intakes draw in exhaust emissions from vehicles, smoke from fires, or other contaminants. Air intakes must be situated to avoid taking in such gases and aerosols. Modifications to an existing facility must also be planned to preclude introducing emissions near building air intakes.

Another component of potential concern in the ventilation system is the exhaust air ejector, or stack. Exhaust air stacks, or facility vent stacks, are chimneys that allow air leaving the facility to be lofted into the atmosphere. Some designs use a fan penthouse on the building roof to loft air upward (no stack is used); other designs use fans at the top of the stack to give extra upward velocity to the air as it leaves the stack for better mixing in the atmosphere. Stacks may pose special concerns with ventilation systems. The type of stack is important to determine if it will pose any concerns about air exhaust flow. In some stacks, a liner of brick is used, and it has been noted at coal-fired power plants that the liner bricks can begin to buckle or lean (Makansi, 1985; Bretz, 1989). This liner swelling or leaning could lead to reduced flow area. Reducing flow area will mean increased air velocity that can erode the liner material and lead to stack sidewall leakage. Liner buckling could possibly lead to reduction in flow out the stack. Metal plate liners could also warp or swell. Stacks must also be checked periodically to verify that they are not plugged by animal encroachment, such as bird nests, etc., rain water accumulation, or ice formation during winter months. Stacks can be very tall (perhaps $30 \mathrm{~m}$ tall) and slender, so they may be susceptible to seismic events. Chen (1993) gives a seismic analysis of a 53.34-m tall stack. Stacks also have radiation monitors to track any radioactive exhaust. Some facilities have had difficulty with lightning striking on or near the stack radiation monitors.

From these operating experiences, some events of concern are noted that should be analyzed in a facility safety assessment:

Partial loss of ventilation air flow (fan fault, fan inadvertently de-energized)

Complete loss of ventilation air flow (fan or control system fault, damper failing shut, loss of site power, etc.)

Ventilation air flow reversal (stack plugging, atmospheric pressure change, etc.)

Loss of filtration efficiency (HEPA filter failure allows air to leak past, or filter depletion) Complete loss of filtration (filter rupture, etc.)

Loss of ventilation zone pressure difference (e.g., filter plugging, damper fault)

Loss of ventilation (air cooling) leads to plant equipment overheating and shut down

Loss of ventilation leads to combustible gas or dust accumulation

Ventilation duct leakage (duct wall cracking, weld failure by vibration, etc.)

Failure to isolate ventilation after an airborne release would allow a stack release after filtration (note that HEPA filtration is not effective on vapors)

Filter fire, releases captured particulate 
Filter failure, (e.g., overpressure, steam-induced tearing, etc.) releases captured particulate

Most of these events cause a loss of the typical pressure zones shown in Figure 1 that confine radiological or toxicological materials. The materials could then migrate or be released from confinement. 


\section{Section 2 References}

Abeln, 1998. S. P. Abeln et al., Design Characteristics for Facilities which Process Hazardous Particulate, LA-UR-2189, CONF-9805118, Los Alamos National Laboratory, May 1998.

ACGIH, 1995. Industrial Ventilation, A Manual of Recommended Practice, twentysecond edition, American Conference of Governmental Industrial Hygienists, Cincinnati, OH, ISBN 1-882417-09-7, 1995, section 6.

AGS, 1998. Guideline for Gloveboxes, second edition, AGS-G001-1998, American Glovebox Society, Santa Rosa, California, ISBN 1-892643-00-6, 1998, section 5.6.

ASHRAE, 1993. Heating, Ventilating, and Air-Conditioning Design Guide for Department of Energy Nuclear Facilities, American Society of Heating, Refrigerating and Air-Conditioning Engineers, Inc., Atlanta, Georgia, ISBN 1883413-03-6, 1993, section 1.

ASME, 1989. Nuclear Power Plant Air-Cleaning Units and Components, ASME N5091989, American Society of Mechanical Engineers, July 1989, section 5.

Beckman, 1993. T. D. Beckman et al., Duct Remediation Program, remediation operations and implementation, RFP-4643, Rocky Flats Plant, 1993.

Bertini, 1980. H. W. Bertini, Descriptions of Selected Accidents that have Occurred at Nuclear Reactor Facilities, ORNL/NSIC-176, Oak Ridge National Laboratory, April 1980.

Bongarra, 1985. J. P. Bongarra et al., Human Factors Design Guidelines for Maintainability of Department of Energy Nuclear Facilities, UCRL-15673, Lawrence Livermore National Laboratory, June 1985.

Bretz, 1989. E. A. Bretz, "New Operating Modes Broaden Quest for Stack Liner Materials,” Power, 133, September 1989, pages 57-60.

Burchsted, 1976. C. A. Burchsted et al., Nuclear Air Cleaning Handbook, design, construction, and testing of high-efficiency air cleaning systems for nuclear applications, ERDA-76-21, Oak Ridge National Laboratory, March 1976.

Cadwallader, 1992. L. C. Cadwallader and D. P. Sanchez, Secondary Containment System Component Failure Data Analysis from 1984 to 1991, EGG-FSP-10323, Idaho National Engineering Laboratory, August 1992. 
Cadwallader, 1998. L. C. Cadwallader, P. A. Pinson, and C. F. Miller, Issues for Reuse of Gloveboxes at LANL TA-55, INEEL-EXT/98-00759, Idaho National Engineering and Environmental Laboratory, August 1998.

Chen, 1993. W. W. Chen et al., Seismic Qualification of Ventilation Stack, WHC-SA2141-FP, CONF 940613027, Westinghouse Hanford Company, October 1993.

Cote, 1991. A. E. Cote and J. L. Linville, editors, Fire Protection Handbook, seventeenth edition, National Fire Protection Association, Quincy, MA, ISBN 0-87765-378-X, 1991, section 6, chapter 16.

Davis, 1999. W. T. Davis and G-D. Kim, "Effect of Prefilters on the Performance of HEPA Filters," Filtration and Separation, 36, April 1999, pages 51-56.

DOE, 1994. US Department of Energy, Operating Experience Review - Ventilation Systems at Department of Energy Facilities, DOE/DP-0125, Washington, DC, May 1994.

DOE, 1997. Type B Accident Investigation Board Report of the July 2, 1997 Curium Intake by Shredder Operator at Building 513 Lawrence Livermore National Laboratory, Livermore, California, DOE/OAK-504, Oakland Operations Office, August 1997. \{shredding HEPA filters led to Curium-244 inhalation\}

DOE, 1999. US Department of Energy, Design Considerations, DOE-HDBK-1132-99, Washington, DC, April 1999.

EIS, 1991. Draft Environmental Impact Statement for the Siting, Construction, and Operation of New Production Reactor Capacity, DOE/EIS-0144D, US Department of Energy, April 1991, volume 4, appendix I.

Grimm, 1998. N. R. Grimm and R. C. Rosaler, HVAC Systems and Components Handbook, second edition, McGraw-Hill Book Company, New York, ISBN 0-07024843-5, 1998, chapter 3.

Haggard, 1996. D. L. Haggard et al., Determination of the Radioactive Material and Plutonium Holdup in Ducts and Piping in the 324 Building, PNNL-10935, Pacific Northwest National Laboratory, January 1996.

Hasegawa, 1992. H. K. Hasegawa et al., Fire Tests to Evaluate the Potential Fire Threat and Its Effects on HEPA Filter Integrity in Cell Ventilation at the Oak Ridge National Laboratory Building 7920, UCRL-CR-114339, Lawrence Livermore National Laboratory, December 1992. 
Holland, 1991. D. F. Holland et al., Potential Off-Normal Events and Releases for the Burning Plasma Experiment, EGG-FSP-7872, revision 3, Idaho National Engineering Laboratory, July 1991.

Howard, 1983. N. M. Howard and M. J. Krasnopoler, "Simplified Tornado Depressurization Design Methods for Nuclear Power Plants," Nuclear Technology, 61, 1983, pages 329-337.

Jacox, 1989. J. W. Jacox, "Review of Nuclear Air Treatment System Related Licensee Event Reports for the Period 1985-1987," Proceedings of the $20^{\text {th }}$ DOE/NRC Nuclear Air Cleaning Conference, NUREG/CP-0098, volume 1, US Nuclear Regulatory Commission, May 1989, pages 386-408.

Lees, 1996. F. P. Lees, Loss Prevention in the Process Industries, hazard identification, assessment and control, second edition, volume 3, Butterworth Hienemann, ISBN 0-7506-1547-8, 1996, Appendix 1, case history A21.

Levenhagen, 1993. J. I. Levenhagen and D. H. Spethmann, HVAC Controls and Systems, McGraw-Hill Inc., New York, ISBN 0-07-037509-7, 1993, chapters 3 and 10.

Lish, 1972. K. C. Lish, Nuclear Power Plant Systems and Equipment, Industrial Press, Inc., New York, ISBN 0-8311-1078-3, 1972, chapter 14.

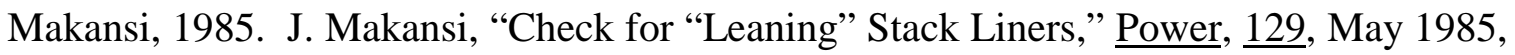
pages 56-57.

Moeller, 1975. D. W. Moeller, "Problems in Nuclear Air-Cleaning Systems," Nuclear Safety, 16, 1975, pages 469-481.

Moeller, 1979. D. W. Moeller, "Failures in Air-Monitoring, Air-Cleaning, and Ventilation Systems in Commercial Nuclear Power Plants (Jan. 1, 1975 - June 30, 1978)," Nuclear Safety, 20, 1979, pages 176-188.

Moeller, 1983. D. W. Moeller and L-S. C. Sun, "Failures in Air-Cleaning, AirMonitoring, and Ventilation Systems in Commercial Nuclear Power Plants, 19781981," Nuclear Safety, 24, 1983, pages 352-371.

Mull, 1998. T. E. Mull, HVAC Principles and Applications Manual, McGraw-Hill, Inc., New York, ISBN 0-07-044451-X, 1998.

NRC, 1981. National Research Council, Prudent Practices for Handling Hazardous Chemicals in Laboratories, National Academy Press, Washington, DC, ISBN 0309-03128-1, 1981, pages 203-205. 
NW, 1990. "USSR Beryllium Factory Explosion Provokes Closure Demonstrations," Nucleonics Week, 31, number 40, October 4, 1990, pages 2-3.

OHS, 1990. "Soviet Beryllium Plant Explodes," Occupational Health and Safety, 59, number 12, November 1990, pages 16-18.

Penicot, 1999. P. Penicot et al., "Clogging of HEPA Fibrous Filters by Solid and Liquid Aerosol Particles: An Experimental Study," Filtration and Separation, 26, 1999, pages 59-64.

Reason, 1983. J. Reason, “Fans,” $\underline{\text { Power, } 127}$, September 1983, pages S-1 to S-24.

Rudinger, 1990. V. Rudinger et al., "High-Strength High-Efficiency Particulate Air Filters for Nuclear Applications," Nuclear Technology, 92, 1990, pages 11-29.

Simiu, 1986. E. Simiu and R. H. Scanlan, Wind Effects on Structures, John Wiley \& Sons, New York, ISBN 0-471-86613-X, 1986, chapter 8.

Walton, 1958. G. N. Walton et al., editors, Glove Boxes and Shielded Cells for handling radioactive materials, Academic Press, Inc., New York, 1958, page 45.

WHC, 1996. Releases from Failed HEPA Filters due to an Overpressurization Event, WHC-SD-WM-CN-063, revision 0, Westinghouse Savannah River Company, August 1996, and also HEPA Filter Fire (and subsequent unfiltered release), WHC-SD-WM-CN-062, 1996.

Wilhelm, 1987. J. Wilhelm, "Development and Application of Filters for Air Cleaning in Nuclear Power Plants," Nuclear Engineering and Design, 103, 1987, pp. 139-147.

Winegardner, 1993. W. K. Winegardner, Aging Assessment of Nuclear Air-Treatment System HEPA Filters and Adsorbers, NUREG/CR-6026, volume 1, US Nuclear Regulatory Commission, August 1993. 


\section{VENTILATION SYSTEM PERSONNEL SAFETY ISSUES}

This chapter contains information about issues of personnel safety in working with ventilation systems. Facility designs often rely on the ventilation system to dilute concentrations of hazardous airborne chemicals or control the spread of dusts in the workplace. Therefore, one personnel safety issue is the ventilation system not operating or not performing to move adequate quantities of air to keep personnel exposures to minimum acceptable levels. The reliability of the system is important for day-to-day personnel safety if small quantities of radiologically or toxicologically hazardous materials are known to be released to the facility atmosphere. The operating ventilation system will remove these small quantities and reduce chronic exposures to the facility personnel.

Ventilation systems are often used to supply air for transferring heat from operating equipment, such as electrical power distribution system cabinets (motor control centers, switch centers, etc.), computerized control equipment, and any other equipment or apparatus that can effectively be cooled by flowing air. Some large electrical motors use ventilation air to cool the motor windings. Using ventilation for cooling means that ventilation is an important support system for other plant equipment. Ventilation failure could lead to loss of electrical power when overtemperature limits cause circuit breakers to open, or erroneous control signals in control computers overheat, or motor loss of function when windings overheat and subsequently arc through damaged insulation. Another safety issue is plant equipment overheating and shutdown after ventilation is interrupted.

Personnel also require air cooling so that their physical activity in the facility does not lead to heat stress. Generally, operators will have the room temperature limits specified in ASHRAE standards for buildings, along with the requirements for moving set amounts of cubic feet per minute per person to assure air cleanliness. Maintainers have room temperature limits described by Bongarra (1985).

Personnel safety was surveyed using a personnel safety master logic diagram (Cadwallader, 1999) to identify those energies and hazardous conditions that pose threats to operations and maintenance personnel. Tables 3 and 4 give the results of that survey.

A list of preventive maintenance (PM) tasks would include:

pre-filter cleaning or replacement

particulate filter DOP test for filtration efficiency

particulate filter changeout; e.g., HEPA filter replacement. Standards recommend using bag-in/bag-out filter changes and using respirators, goggles, gloves and protective clothing for the safety of maintenance personnel (AIHA, 1992; DOE, 1999).

vapor filter regeneration or media changeout, e.g., activated carbon filter renewal duct and filter leaktightness test

scrubber cleaning 
demister cleaning or replacement

motor PM, including examination of lubrication sumps, adding lubricant 
Table 3. Potential ventilation safety issues for operations personnel

\begin{tabular}{|c|c|}
\hline $\begin{array}{l}\text { Energy source for } \\
\text { exposure to operators }\end{array}$ & Origin of energy source \\
\hline Acoustic energy & $\begin{array}{l}\text { Air movement noise in ducts, grille, louvers, and } \\
\text { diffusers (whistling, etc.); air leakage noise from ducts, } \\
\text { fans; fan operation noise }\end{array}$ \\
\hline Chemical energy & $\begin{array}{l}\text { Possibility of dust and other irritants building up in ducts } \\
\text { and being distributed in the facility. Substandard } \\
\text { ventilation will allow process materials to build up in the } \\
\text { work areas, this could be hazardous. }\end{array}$ \\
\hline Electrical energy & $\begin{array}{l}\text { Static electricity can accumulate unless air relative } \\
\text { humidity is kept above } 55 \% \text {. }\end{array}$ \\
\hline Kinetic energy & $\begin{array}{l}\text { Rotating shaft energy in fans, possible impact by fan } \\
\text { blade pieces or by objects thrown by fan blades }\end{array}$ \\
\hline Mechanical energy & $\begin{array}{l}\text { Exposed damper linkage arms can bind or pinch, valve } \\
\text { stems could also pinch. }\end{array}$ \\
\hline Pressure energy & $\begin{array}{l}\text { Air is generally low pressure in these systems, there } \\
\text { could be exposure from steam heating coils or water } \\
\text { cooling coils for air treatment. That is outside the scope } \\
\text { of this study. There could be pneumatic drive systems } \\
\text { for dampers, operating at low pressure, perhaps } 15 \text { psig. }\end{array}$ \\
\hline Radiation energy & $\begin{array}{l}\text { The only ionizing radiation sources could be radioactive } \\
\text { particle plate out on the duct walls, and accumulation of } \\
\text { radioactive materials in the air filters. } \\
\text { No non-ionizing radiation sources are known to be used } \\
\text { in ventilation systems, besides the small electromagnetic } \\
\text { fields from electric motors. }\end{array}$ \\
\hline Thermal energy & $\begin{array}{l}\text { Possible exposure from steam heating coils or water } \\
\text { cooling coils for air treatment. Recall one air cooler } \\
\text { leaked a very large amount of water in a facility. } \\
\text { If ventilation does not cool facility air adequately, } \\
\text { personnel could overheat. This is especially true if they } \\
\text { are in anti-contamination clothing, performing heavy } \\
\text { labor, etc. }\end{array}$ \\
\hline Vibration energy & $\begin{array}{l}\text { Unbalanced fan blades can vibrate the fan casing and } \\
\text { duct. Poor duct design can allow air flow-induced } \\
\text { vibration of ducts. This leads to noise and mechanical } \\
\text { vibration. }\end{array}$ \\
\hline Biological hazard (fungi) & $\begin{array}{l}\text { Fungi could grow in humid ducts, exposing personnel as } \\
\text { air passes over the growth. This is sometimes referred to } \\
\text { as "Sick Building Syndrome." }\end{array}$ \\
\hline
\end{tabular}


Table 4. Potential ventilation safety issues for maintenance personnel

\begin{tabular}{|c|c|}
\hline $\begin{array}{c}\text { Energy source for } \\
\text { exposure to maintainers }\end{array}$ & Origin of energy source \\
\hline Acoustic energy & $\begin{array}{l}\text { Air leakage noise from ducts, fans; fan and compressor } \\
\text { operation noise }\end{array}$ \\
\hline Chemical energy & $\begin{array}{l}\text { Possibility of dust and other irritants building up in duct } \\
\text { work. Welding fumes could be present in some } \\
\text { maintenance, such as a duct patching or replacement task. } \\
\text { Exposure to lubricants, such as grease and bearing oil. }\end{array}$ \\
\hline Electrical energy & $\begin{array}{l}\text { Motive power to fan motors ( } 480 \mathrm{~V} \text { and higher), damper } \\
\text { motors }(24 \mathrm{~V}) \text {, and valve motors. Power to tools used for } \\
\text { maintenance, instrumentation power. }\end{array}$ \\
\hline Gravitational energy & $\begin{array}{l}\text { Working at heights to access overhead ducts and diffusers, } \\
\text { fan lofts, roof units, etc. Objects (tools, filters, etc.) could } \\
\text { be dropped onto workers. Cranes might be used to hoist } \\
\text { equipment, such as fan motors, so the possibility of a } \\
\text { dropped load must be considered. }\end{array}$ \\
\hline Kinetic energy & $\begin{array}{l}\text { Rotating shaft energy in fans, keep clear to avoid being } \\
\text { wrapped on shaft. Possible impact by fan blade pieces or } \\
\text { by objects thrown by fan blades }\end{array}$ \\
\hline Mechanical energy & $\begin{array}{l}\text { Damper louvers and linkage arms could pinch. Filter } \\
\text { replacement could allow pinching of hands or arms. Belt } \\
\text { driven equipment could provide pinch points for workers. }\end{array}$ \\
\hline Pressure energy & $\begin{array}{l}\text { Air is generally low pressure in these systems, there could } \\
\text { be exposure from steam heating coils or water cooling } \\
\text { coils for air treatment. Water could flood. There could be } \\
\text { pneumatic drive systems for dampers, operating at low } \\
\text { pressure. Some tools might operate under pressure, such } \\
\text { as water sprays for duct cleaning, pneumatic wrenches, etc. }\end{array}$ \\
\hline Radiation energy & $\begin{array}{l}\text { The only ionizing radiation sources could be radioactive } \\
\text { particle plate out on the duct walls, or accumulation in the } \\
\text { air filters. } \\
\text { Small electromagnetic fields from fan motors and powered } \\
\text { tools. Welding gives off ultraviolet light. }\end{array}$ \\
\hline Thermal energy & $\begin{array}{l}\text { Possible exposure from steam heating coils or water } \\
\text { cooling coils for air treatment. Water could flood. } \\
\text { Maintenance tools, such as welding to patch a duct, could } \\
\text { expose workers to heat. }\end{array}$ \\
\hline Vibration energy & $\begin{array}{l}\text { Unbalanced fan blades can vibrate the fan casing and duct } \\
\text { work. Tools may also vibrate. }\end{array}$ \\
\hline Biological hazard (fungi) & $\begin{array}{l}\text { Fungi could grow in humid duct work, exposing personnel } \\
\text { as air passes over the growth. Periodic duct cleaning } \\
\text { activities could lead to high exposures. }\end{array}$ \\
\hline
\end{tabular}


valve adjustment and PM, including examination of lubrication sumps, adding lubricant, valve seal cleaning and/or replacement

fan blade balancing, fan blade cleaning and inspection for blade material integrity

AHU liner integrity inspection

fan vibration tests

drive belt inspection

duct cleaning

instrument calibration (temperature, humidity, and pressure instruments)

air sampling for contaminants

air flow and air flow balance testing

system isolation testing

As mentioned briefly in section 2, filters accumulate radioactive or hazardous particulate. Used filters must be treated with care during replacement and disposal. The event referred to in section 2 discussed how used glovebox HEPA filters were being compacted for disposal by shredding with a knife shredder machine. The filters released Curium244, which led to worker inhalation exposures despite respirator protection (DOE, 1997).

The typical walkdown inspection is not as detailed as the PM tasks. A daily walkdown is intended to sense if any equipment is not functioning correctly. Sensing the heat in the equipment area, the noise the equipment produces, detecting smoke and smelling any smells of overheating; these are walkdown tasks. Issues to note could be bearings "singing" that denote bearing chafing that leads to bearing failure, or the sizzling noise or "bacon frying" sound of a cavitating water coolant pump. Vibration noise of fan blades not spinning true (i.e., precessing on the fan shaft) and equipment mounting tightness are daily walkdown items to note. Other visual inspection guidance is given by the ASME (1989), including the condition of housekeeping, damage to instrumentation, verifying that sample port plugs are in place, verifying that seals on the system are not leaking, etc.

Bloch (1985) also has some discussion about PM tasks. When blowing dust from fan motor windings, air pressure over 50 psig will blow dust under insulation tape and the blowing dust can damage the surface of insulation. Inspection of liners in AHUs and duct work is important to determine if liner debris will be spreading throughout the system.

A list of corrective maintenance tasks would include:

fan replacement

drive belt replacement

fan motor replacement

instrument replacement

valve repacking, valve replacement

Industrial HVAC operators agree that proper maintenance is the single greatest influence on HVAC equipment lifetime (McRae, 1988). Some average service lifetimes before replacement for fans are 10 to 20 years, depending on the fan type and duty factor, and 10 
years for blade dampers (McRae, 1988). Some other estimates are for ducts, the life of the facility; gauges, 15 years; fresh air louvers made of steel, 15 years; compressors, 20 years (Akalin, 1978). Unfortunately, these authors did not discuss the times for maintenance actions. Equipment useful lifetimes are important for reliability and economics calculations. Many of the cited equipment lifetimes are shorter than facility lifetime. Fusion experiment facilities are operated typically on the order of 15 years, and a fusion power plant may be operated on the order of 40 to 60 years. Therefore, major equipment replacement tasks are expected to occur, with their attendant hazards of crane lifts, complete electrical and support system isolation lockout tagout, uncovering openings in the facility, prolonged work in confined spaces, and other hazards of equipment replacement.

To provide for maintainer safety, work planners must recall that ventilation systems have several support systems that must have energy lock-outs performed to prevent injuries during maintenance tasks. The support systems are electrical power, perhaps a plant compressed air supply, water supplies, and instrumentation and control signal interfaces. Fan sizes and types will set specific input power requirements, but 480 Volt systems are not uncommon for moving reasonably large amounts of air, and 4160 Volt units move very large amounts of air. Damper motors are typically controlled using 24 Volt power or plant air. Compressed air for damper positioning is often operated in the 3 to 15 psig range. Since occupational safety and health regulations state that personnel exposure to compressed air for cleaning shall be less than $30 \mathrm{psig}$ (CFR, 1999), the lower pressures of 3 to 15 psig are within safe levels. The reader will recall that Bloch (1985) suggested less than 50 psig to use for removing dust from motor windings; under 30 psig should be used to comply with regulations. Even less than 30 psig may still raise particulate from ventilation duct walls. Particulate can be nuisance dusts or more hazardous materials.

Working at heights must include proper safety precautions. An event in 1977 (DOE, 1980) illustrated this point. A maintenance craftsman was fatally injured after being catapulted 25 feet from the roof of a building to the ground. The accident occurred while lowering an air conditioner cooling coil from the roof with a mobile hoist unit.

Ventilation systems have been known to accumulate hazardous particulate in the duct work, for example, the glovebox ventilation ducts at Rocky Flats accumulated plutonium as discussed in section 2. Maintenance personnel can be exposed to various chemical substances from aerosol and particulate buildup on the interior surfaces of ducts if duct cleaning, maintenance of fans, valves, or instruments require a duct to be opened. Another issue of concern is mold growth in water collection trays and on the duct pipe walls. Mold can also grow in humidification pans and transmit to the duct walls. Instrumentation, such as manometers or pitot tubes, can become contaminated and must be handled with caution.

Some ventilation system tasks might require personnel entry into AHUs or filter arrays for cleaning or inspection. When personnel enter those areas, confined space entry procedures are needed (CFR, 1999a). 
A key feature in protecting maintenance personnel is to inspect the ventilation systems and assess what hazards exist before performing any tasks. With hazards characterized, then proper controls can be established to provide for safe work. 


\section{Section 3 References}

AIHA, 1992. American National Standard for Laboratory Ventilation, AIHA/ANSI Z9.51992, American Industrial Hygiene Association and American National Standards Institute, September 15, 1992.

Akalin, 1978. M. T. Akalin, "Equipment Life and Maintenance Cost Survey," ASHRAE Journal, 20, October 1978, pages 40-44.

ASME, 1989. Testing of Nuclear Air Treatment Systems, ASME N510-1989, American Society of Mechanical Engineers, December 1989, section 5.5.1.

Bloch, 1985. H. P. Bloch and F. K. Geitner, Major Process Equipment Maintenance and Repair, Gulf Publishing Company, Houston, TX, ISBN 0-87201-454-1, 1985, chapter 4.

Cadwallader, 1999. L. C. Cadwallader, "Preliminary Master Logic Diagram for Personnel Safety," Proceedings of the International Topical Meeting on Probabilistic Safety Assessment (PSA '99), risk-informed performance-based regulation in the New Millennium, Washington, DC, August 22-26, 1999, American Nuclear Society, pages 1409-1416.

CFR, 1999. Title 29, Labor, Code of Federal Regulations, Part 1910.242, Washington, DC, July 1999.

CFR, 1999a. Title 29, Labor, Code of Federal Regulations, Part 1910.146, Washington, DC, July 1999.

DOE, 1980. Operational Accidents and Radiation Exposures at ERDA Facilities 19751977, DOE/EV-0080, US Department of Energy, May 1980.

DOE, 1997. Type B Accident Investigation Board Report of the July 2, 1997 Curium Intake by Shredder Operator at Building 513 Lawrence Livermore National Laboratory, Livermore, California, DOE/OAK-504, Oakland Operations Office, August 1997.

DOE, 1999. US Department of Energy, Design Considerations, DOE-HDBK-1132-99, Washington, DC, April 1999.

McRae, 1988. M. R. McRae et al., "Service Life of Energy Conservation Measures," ASHRAE Journal, 30, December 1988, pages 25-28. 


\section{VENTILATION SYSTEM COMPONENT FAILURE RATES}

This section gives component failure rates for the major ventilation system components described in chapter 2. In general, nuclear component failure rates have been surveyed and selected for application for fusion usage. Some non-fission data have been given here for comparison to the fission values.

\subsection{Component failure rates}

Table 5 gives failure rates for ventilation system components. The failure modes and statistical error are also given in the table. These values have come primarily from nuclear fission sources, which does not pose any large error since the applications are very similar. Several published sources of ventilation system studies (Sarver, 1975; Durant, 1980; Khan, 1991) were consulted along with the system description in Chapter 2 to determine the necessary components to be included in the data set development. The data in the table come from matured components and are constant failure rate values. Lofaro (1993) cited 6 months as the burn-in time for ventilating system components.

Failure rate data could not be found for a few components listed in section 2. The air sampling system was one of those. Alber (1995) gave a failure rate value for an INEEL chemical sampling system using a needle probe for sample pickup. The chemical sampler failure rate of 1E-05/hour was for all failure modes, with an error factor of 8 . Until further data are found, then using an air sampler failure rate in the 1E-05/hour range is probably adequate. Vessel vent systems were not included here since these systems are specialized equipment. Some treatment of rupture disks and other vent equipment is found in Cadwallader (1998). Condensers were not treated for the same reason as vessel vent systems. Fire suppression systems have been assigned some data in Cadwallader (1995). Heat removal systems were not treated since these are also not germane to the ventilation confinement function for fusion systems; the same reason holds for criticality drains. Blanton (1993) gave some values for fan coolers (fails to start, 1E-02/d with error factor of 5, and fails to run, 1E-05/h with an error factor of 3). Alber (1995) gave an overall ventilation system failure rate for 'all modes' of $2.4 \mathrm{E}-05 / \mathrm{h}$ with an error factor of 6.9 , and a ventilation system leakage failure rate of $5.24 \mathrm{E}-06 / \mathrm{h}$ with an error factor of 6.8 . A conservative upper bound failure to isolate a ventilation system on release of hazardous material to room air has been estimated at 1E-02/d (Holland, 1991).

Some operational data on air detritiation systems is given in Cadwallader (1993). 
Table 5. Ventilation system component failure rates

\begin{tabular}{|c|c|c|c|c|}
\hline Component & Failure mode & $\begin{array}{c}\text { Recommended } \\
\text { average failure } \\
\text { rate }\end{array}$ & Error factor & Reference \\
\hline \multirow[t]{2}{*}{ Fan } & Fails to run & $3 \mathrm{E}-05 / \mathrm{h}$ & 10 & Eide, 1990 \\
\hline & Fails to start & $5 \mathrm{E}-03 / \mathrm{d}$ & 5 & Eide, 1990 \\
\hline \multirow[t]{2}{*}{ Duct } & Leakage & 1E-09/h-m & 10 & Eide, 1990 \\
\hline & Blockage & $\begin{array}{l}\text { none for }>10 \mathrm{~cm} \\
\text { diameter piping }\end{array}$ & -- & -- \\
\hline \multirow[t]{2}{*}{ Pre-Filter } & Internal leakage & $3 \mathrm{E}-06 / \mathrm{h}$ & 10 & Blanton ,1993 \\
\hline & Plugging & $3 \mathrm{E}-06 / \mathrm{h}$ & 10 & Blanton, 1993 \\
\hline \multirow[t]{2}{*}{ HEPA filter } & Internal leakage & $3 \mathrm{E}-06 / \mathrm{h}$ & 10 & Blanton, 1993 \\
\hline & Plugging & $1 \mathrm{E}-05 / \mathrm{h}$ & 10 & Eide, 1990 \\
\hline \multirow[t]{2}{*}{ Damper } & $\begin{array}{l}\text { Fail to } \\
\text { open/close }\end{array}$ & $3 \mathrm{E}-03 / \mathrm{d}$ & 5 & Eide, 1990 \\
\hline & $\begin{array}{l}\text { Spurious } \\
\text { operation }\end{array}$ & $3 \mathrm{E}-07 / \mathrm{h}$ & 10 & Eide, 1990 \\
\hline \multirow[t]{2}{*}{ Butterfly valve } & "all modes" & $1.2 \mathrm{E}-06 / \mathrm{h}$ & 30 & IAEA (1988) \\
\hline & Fail to open & $1 \mathrm{E}-03 / \mathrm{d}$ & $10 ?$ & assumed \\
\hline $\begin{array}{l}\text { Pressure } \\
\text { monitor }\end{array}$ & Fail to operate & $1 \mathrm{E}-06 / \mathrm{h}$ & 3 & $\begin{array}{l}\text { Cadwallader, } \\
1998\end{array}$ \\
\hline $\begin{array}{l}\text { Thermocouple } \\
\text { temperature } \\
\text { monitor }\end{array}$ & Fail to operate & $1 \mathrm{E}-06 / \mathrm{h}$ & 3 & $\begin{array}{l}\text { Cadwallader, } \\
1998\end{array}$ \\
\hline $\begin{array}{l}\text { Radiation } \\
\text { monitor }\end{array}$ & Fail to operate & $1 \mathrm{E}-06 / \mathrm{h}$ & 10 & $\begin{array}{l}\text { Cadwallader, } \\
1998\end{array}$ \\
\hline Exhaust stack & Leakage & $1 \mathrm{E}-08 / \mathrm{h}-\mathrm{m}$ & 10 & $\begin{array}{l}\text { Cadwallader, } \\
1998\end{array}$ \\
\hline \multirow[t]{2}{*}{$\begin{array}{l}\text { Fire or smoke } \\
\text { damper }\end{array}$} & $\begin{array}{l}\text { Fails on } \\
\text { demand }\end{array}$ & $2.7 \mathrm{E}-04 / \mathrm{d}$ & 4.4 & Eide, 1990 \\
\hline & $\begin{array}{l}\text { Spurious } \\
\text { operation }\end{array}$ & $1 \mathrm{E}-08 / \mathrm{h}$ & 3 & Eide, 1990 \\
\hline Demister & Fail to run & $1 \mathrm{E}-04 / \mathrm{h}$ & 10 & Blanton, 1993 \\
\hline \multirow[t]{2}{*}{ Scrubber, wet } & $\begin{array}{l}\text { Fail to start on } \\
\text { demand }\end{array}$ & $1 \mathrm{E}-02 / \mathrm{d}$ & 10 & $\begin{array}{l}\text { Cadwallader, } \\
1998\end{array}$ \\
\hline & Fail to operate & $8 \mathrm{E}-06 / \mathrm{h}$ & 10 & $\begin{array}{l}\text { Cadwallader, } \\
1998\end{array}$ \\
\hline \multirow[t]{2}{*}{ Scrubber, dry } & Plugging & $1 \mathrm{E}-04 / \mathrm{h}$ & 10 & $\begin{array}{l}\text { Cadwallader, } \\
1998\end{array}$ \\
\hline & Internal leakage & $1 \mathrm{E}-05 / \mathrm{h}$ & 10 & $\begin{array}{l}\text { Cadwallader, } \\
1998\end{array}$ \\
\hline \multirow[t]{3}{*}{ Sand filter } & Plugging & $3 \mathrm{E}-06 / \mathrm{h}$ & 10 & Eide, 1990 \\
\hline & Internal rupture & $5 \mathrm{E}-07 / \mathrm{h}$ & 10 & Blanton, 1993 \\
\hline & Internal leakage & $3 \mathrm{E}-06 / \mathrm{h}$ & 10 & Blanton, 1993 \\
\hline
\end{tabular}


Table 6. Ventilation system failure rate comparisons

\begin{tabular}{|c|c|c|c|c|}
\hline Component & Failure mode & $\begin{array}{l}\text { Recommended } \\
\text { average failure } \\
\text { rate }\end{array}$ & $\begin{array}{c}\text { Comparison } \\
\text { failure rate } \\
\text { value }\end{array}$ & $\begin{array}{c}\text { Comparison } \\
\text { results }\end{array}$ \\
\hline \multirow[t]{2}{*}{ Fan } & Fails to run & $3 \mathrm{E}-05 / \mathrm{h}$ & $4 \mathrm{E}-06 / \mathrm{h} \quad$ AM & Poor \\
\hline & Fails to start & $5 \mathrm{E}-03 / \mathrm{d}$ & -- & \\
\hline \multirow[t]{2}{*}{ Duct } & Leakage & $1 \mathrm{E}-09 / \mathrm{h}-\mathrm{m}$ & $6 \mathrm{E}-07 / \mathrm{h} \quad$ AM & duct - Poor \\
\hline & Blockage & $\begin{array}{c}\text { none for }>10 \mathrm{~cm} \\
\text { diameter piping }\end{array}$ & none & \\
\hline \multirow[t]{2}{*}{ Pre-Filter } & Internal leakage & $3 \mathrm{E}-06 / \mathrm{h}$ & $1.2 \mathrm{E}-06 / \mathrm{h} \quad \mathrm{AM}$ & $\begin{array}{l}\text { Good } \\
\text { comparison }\end{array}$ \\
\hline & Plugging & $3 \mathrm{E}-06 / \mathrm{h}$ & & \\
\hline \multirow[t]{2}{*}{ HEPA filter } & Internal leakage & $3 \mathrm{E}-06 / \mathrm{h}$ & & \\
\hline & Plugging & $1 \mathrm{E}-05 / \mathrm{h}$ & $1.2 \mathrm{E}-06 / \mathrm{h} \quad$ AM & Fair \\
\hline \multirow[t]{2}{*}{ Damper } & $\begin{array}{l}\text { Fail to } \\
\text { open/close }\end{array}$ & $3 \mathrm{E}-03 / \mathrm{d}$ & - & \\
\hline & $\begin{array}{l}\text { Spurious } \\
\text { operation }\end{array}$ & $3 \mathrm{E}-07 / \mathrm{h}$ & & \\
\hline Butterfly valve & "all modes" & $1.2 \mathrm{E}-06 / \mathrm{h}$ & -- & -- \\
\hline $\begin{array}{l}\text { Pressure } \\
\text { monitor }\end{array}$ & Fail to operate & $1 \mathrm{E}-06 / \mathrm{h}$ & $2.3 \mathrm{E}-05 / \mathrm{h} \quad \mathrm{AM}$ & $\begin{array}{l}\text { General sensor } \\
\text { value was } \\
3 \mathrm{E}-06 / \mathrm{h} \text {, Good } \\
\text { comparison }\end{array}$ \\
\hline $\begin{array}{l}\text { Thermocouple } \\
\text { temperature } \\
\text { monitor }\end{array}$ & Fail to operate & $1 \mathrm{E}-06 / \mathrm{h}$ & $1.2 \mathrm{E}-05 / \mathrm{h} \quad \mathrm{AM}$ & Fair \\
\hline $\begin{array}{l}\text { Radiation } \\
\text { monitor }\end{array}$ & Fail to operate & $1 \mathrm{E}-06 / \mathrm{h}$ & -- & \\
\hline Exhaust stack & Leakage & 1E-08/h-m & -- & \\
\hline \multirow[t]{2}{*}{$\begin{array}{l}\text { Fire or smoke } \\
\text { damper }\end{array}$} & $\begin{array}{l}\text { Fails on } \\
\text { demand }\end{array}$ & $2.7 \mathrm{E}-04 / \mathrm{d}$ & -- & \\
\hline & $\begin{array}{l}\text { Spurious } \\
\text { operation }\end{array}$ & $1 \mathrm{E}-08 / \mathrm{h}$ & & \\
\hline Demister & Fail to run & $5 \mathrm{E}-06 / \mathrm{h}$ & -- & \\
\hline \multirow[t]{2}{*}{ Scrubber, wet } & $\begin{array}{l}\text { Fail to start on } \\
\text { demand }\end{array}$ & $1 \mathrm{E}-02 / \mathrm{d}$ & -- & \\
\hline & Fail to operate & $8 \mathrm{E}-06 / \mathrm{h}$ & & \\
\hline \multirow[t]{2}{*}{ Scrubber, dry } & Plugging & $1 \mathrm{E}-04 / \mathrm{h}$ & -- & \\
\hline & Internal leakage & $1 \mathrm{E}-05 / \mathrm{h}$ & & \\
\hline \multirow[t]{3}{*}{ Sand filter } & Plugging & $3 \mathrm{E}-06 / \mathrm{h}$ & -- & \\
\hline & Internal rupture & $5 \mathrm{E}-07 / \mathrm{h}$ & & \\
\hline & Internal leakage & $3 \mathrm{E}-06 / \mathrm{h}$ & & \\
\hline
\end{tabular}

Note: Military data were taken from NPRD (1991). Ground fixed values were used here. AM stands for 'all modes'. 
The International Energy Agency agreement on Environmental, Safety and Economic Aspects of Fusion Power has a task on failure rate data collection. The participants in this task agreed to compare their data to independent data sets to determine if there were any wide discrepancies in the data being used for fusion safety studies. The agreement was if data were within a factor of 3 , then the data compared well, or good. Within a factor of 10, the data were fair, and beyond a factor of 10, the data compared poorly. Such a comparison was made and shown in Table 6 . The results are that some values were fair comparisons and some were poor. The first issue to examine in the poor comparisons was that the military values were 'all failure modes' values rather than failure mode-specific values, so there will be some fractional discrepancy with the values due to the way the data were calculated and presented. The poor comparisons are probably partly due to differences in equipment. The fan sizes were not given, so it is possible that the "ground fixed" military fans were not as large as the power plant ventilation units. Looking at a fan failure rate from the chemical industry gives an average failure rate of $9 \mathrm{E}-06 / \mathrm{h}$ (AIChE, 1989), which is in fair agreement with the nuclear fan value. The military data had air duct values, but these are probably sheet metal, not piping. The nuclear data came from piping, since the nuclear air ducts are steel piping rather than sheet metal ducts. The military data did not have piping values in the data set. Several other components were not in the military data set. Scrubbers, dampers, several types of monitors could not be compared for that reason.

The nuclear values in Table 5 are still suggested for use in safety or risk studies of fusion facilities, since the data accumulation was on facilities very similar to fusion experiments. The comparison with military data was an independent check of values, and many of the values were in the "fair" range.

\subsection{Component repair times}

Table 7 gives some estimates of repair times for some of the ventilation equipment. The industrial group, ASHRAE, did not report maintenance times, they gave yearly maintenance costs per square foot of facility being served by a ventilation system. Those data might yield some useful safety information, but too many assumptions were needed to arrive at any component-specific repair time data from ASHRAE. The ASHRAE values for component lifetimes cited earlier are useful to understand that major ventilation component replacements will occur once or more over the life of the facility. Another concern about repair times was that if a ventilation system might become contaminated, then nuclear 'as-low-as-reasonably-achievable' techniques for exposure and contamination would have to be followed, and these techniques would add time to the repair tasks. Therefore, nuclear times are more likely a better data set than commercial or industrial data. A good set of nuclear equipment maintenance times is found in Hannaman (1978), and some of those times are cited here. Some generalized major maintenance act time ranges were also given in the WASH-1400 Reactor Safety Study (NRC, 1975), such as valves, 1 to 350 hours with an average time of 24 hours, and instruments 0.25 to 72 hours, with an average time of 7 hours. Equipment tests were generally in the 0.25 to 4 hour time duration range, with an average of 1 hour duration. 
Table 7. Repair time estimates for ventilation system components

\begin{tabular}{|c|c|c|c|}
\hline Component & $\begin{array}{l}\text { Recommended } \\
\text { average time to } \\
\text { repair (h) }\end{array}$ & $\begin{array}{c}\text { High estimate } \\
\text { of repair time } \\
\text { (h) }\end{array}$ & Reference \\
\hline Fan & 40 & 400 & $\begin{array}{l}\text { Hannaman, } \\
\text { 1978; also } \\
\text { IAEA, } 1988 \\
\text { cited a } 40 \text { hour } \\
\text { average time }\end{array}$ \\
\hline Duct & 30 & 100 & $\begin{array}{l}\text { Hannaman, } \\
1978\end{array}$ \\
\hline Pre-Filter & 0.5 & 2 & Wright, 1987 \\
\hline HEPA filter & 2 & 8 & Wright, 1987 \\
\hline Damper & 0.6 & not given & IAEA, 1988 \\
\hline Butterfly valve & 1.9 & not given & IAEA, 1988 \\
\hline $\begin{array}{l}\text { Pressure } \\
\text { monitor }\end{array}$ & 6 & 70 & $\begin{array}{l}\text { Hannaman, } \\
1978\end{array}$ \\
\hline $\begin{array}{l}\text { Thermocouple } \\
\text { temperature } \\
\text { monitor }\end{array}$ & 6 & 70 & $\begin{array}{l}\text { Hannaman, } \\
1978\end{array}$ \\
\hline $\begin{array}{l}\text { Radiation } \\
\text { monitor }\end{array}$ & 6 & 70 & $\begin{array}{l}\text { Hannaman, } \\
1978\end{array}$ \\
\hline Exhaust stack & -- & & -- \\
\hline $\begin{array}{l}\text { Fire or smoke } \\
\text { damper }\end{array}$ & 0.6 & & IAEA, 1988 \\
\hline Scrubber, wet & -- & & -- \\
\hline Scrubber, dry & -- & & -- \\
\hline Sand filter & -- & & -- \\
\hline
\end{tabular}

note: for a stand-alone blower fan, IAEA (1988) gave a 1.5 hour repair time 


\section{Section 4 References}

AIChE, 1989. Guidelines for Process Equipment Reliability Data, with data tables, Center for Chemical Process Safety, American Institute of Chemical Engineers, 1989, page 191.

Alber, 1995. T. G. Alber et al., Idaho Chemical Processing Plant Failure Rate Database, INEL-95/0422, Idaho National Engineering Laboratory, August 1995.

Blanton, 1993. C. H. Blanton and S. A. Eide, Savannah River Site Generic Data Base Development, WSRC-TR-93-262, Westinghouse Savannah River Company, June 1993.

Cadwallader, 1993. L. C. Cadwallader and G. Taylor, Experimental Tritium Cleanup System Availability Analysis from 1984 to 1992, EGG-FSP-10603, Idaho National Engineering Laboratory, May 1993.

Cadwallader, 1995. L. C. Cadwallader, Fire Protection System Operating Experience Review for Fusion Applications, INEL-95/0396, Idaho National Engineering Laboratory, December 1995.

Cadwallader, 1996. L. C. Cadwallader, Reliability Estimates for Selected Sensors in Fusion Applications, INEL-96/0295, Idaho National Engineering Laboratory, September 1996.

Cadwallader, 1998. L. C. Cadwallader, Selected Component Failure Rate Values from Fusion Safety Assessment Tasks, INEEL/EXT-98-00892, Idaho National Engineering and Environmental Laboratory, September 1998.

Durant, 1980. W. S. Durant, Expected Failure Frequency of H-Canyon and HB-Line Exhaust Fans, DPST-80-262, DE85-018517, Savannah River Laboratory, February 1, 1980.

Eide, 1990. S. A. Eide et al., Generic Component Failure Data Base for Light Water and Liquid Sodium Reactor PRAs, EGG-SSRE-8875, Idaho National Engineering Laboratory, February 1990.

Hannaman, 1978. G. W. Hannaman, GCR Reliability Data Bank Status Report, GAA14839, General Atomics, July 1978.

Holland, 1991. D. F. Holland et al., Potential Off-Normal Events and Releases for the Burning Plasma Experiment, EGG-FSP-7872, revision 3, Idaho National Engineering Laboratory, July 1991. 
IAEA, 1988. Component Reliability Data for Use in Probabilistic Safety Assessment, IAEA-TECDOC-478, International Atomic Energy Agency, Vienna, 1988, pages 101, 123, 131, 232.

Khan, 1991. S. A. Khan, "Reliability Assessment of Emergency Exhaust System in a Pool-type Research Reactor," Nuclear Engineering and Design, 131, 1991, pages 37-60.

Lofaro, 1993. R. J. Lofaro, Understanding Aging in Containment Cooling Systems, BNL-NUREG-49711, CONF 931079-14, Brookhaven National Laboratory, 1993.

NPRD, 1991. Nonelectronic Parts Reliability Data, 1991, NPRD-91, Reliability Analysis Center, Rome, NY, May 1991.

NRC, 1975. N. C. Rasmussen et al., Reactor Safety Study - An Assessment of Accident Risks in U.S. Commercial Nuclear Power Plants, WASH-1400, NUREG-75/014, US Nuclear Regulatory Commission, October 1975, Appendix III.

Sarver, 1975. S. J. Sarver, "Reliability Evaluation of a Containment Fan Cooler System," Proceedings of the 1975 Annual Reliability and Maintainability Symposium, Washington DC, 28-30 January, 1975, Institute of Electrical and Electronics Engineers, 1975, pages 154-162.

Wright, 1987. R. E. Wright and M. B. Sattison, A RAM Analysis of the Proposed Tinker AFB Jet Fuel Storage Tank Facility, EGG-REQ-7807, Idaho National Engineering Laboratory, August 1987. 


\section{CONCLUSIONS}

Ventilation systems are important for confining and controlling chemical and radiological materials. This report gives operating experiences and quantitative data on failures and repair times for ventilation equipment. These data will be useful for safety studies of vapor or particulate release in magnetic or inertial fusion experiments. Individual facility ventilation system designs will need to be analyzed and modeled with fault trees to determine the likelihood of a ventilation failure or isolation failure in an accident event. The experiences discussed in section 2 should help identify accident-initiating events for modeling. The failure rate data in section 4 should provide quantification of those fault trees. The data in this report may also be useful for maintenance planning, including issues to routinely examine, issues to address for the safety of personnel, and reliabilityavailability-maintainability (RAM) analysis of the system, if needed. 